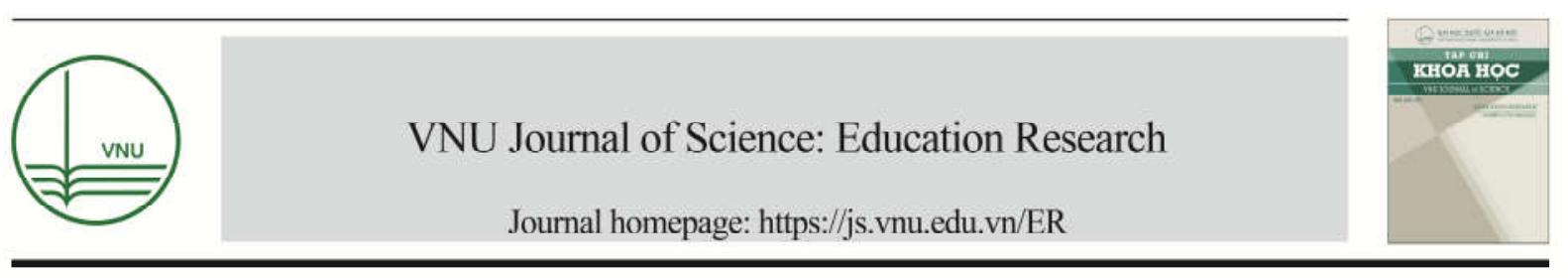

\title{
Organizing Bilingual Biology Lessons to Develop English Skills in High School Students
}

\author{
Tran Trung Hieu* \\ Department of Education, An Giang University, \\ No. 18 Ung Van Khiem, Dong Xuyen, Long Xuyen, An Giang, Vietnam \\ Received 09 April 2018 \\ Revised 17 May 2018; Accepted 18 May 2018
}

\begin{abstract}
English is one of the most vital and necessary tools for people's successes in many aspects of life. Therefore, building good ways to develop English skills in students is an urgent demand. Organizing English-Vietnamese bilingual lesson is interpreted as educational method in which a foreign language enrichment measure packaged into content teaching, so it is one of the effective ways to improve this skill for students. By investigating 457 students and 27 high school biology teachers in An Giang province, the study pointed out two issues of the reality of using English in biology teaching in high schools: (1) Teachers have rarely used English in teaching activities, (2) Students' English ability has been really weak. The study has also built up the processes of organizing an English-Vietnamese bilingual lesson. The paper demonstrated that high school students' English ability and qualification has been improved by using these proposed processes.
\end{abstract}

Keywords: Bilingual biology lessons, bilingual teaching, English ability, biology teaching.

\section{Introduction}

In Vietnam, some subjects in few high schools have been taught in English or French. Although these learners follow completely the educational program and improve foreign language ability, the majority of Vietnamese students have been really weak in foreign language (especially English). Most of them and majority of post-graduate students cannot read their documents written in foreign languages, communicate with foreign partners

\footnotetext{
*Tel.: 84-986306802.

Email: trunghieu.bio.ag@gmail.com

https://doi.org/10.25073/2588-1159/vnuer.4131
}

although they have learnt English from elementary school [1-3].

The main reason of this weakness is teaching method in which foreign languages have been taught seperately with other subjects [4]. As a result, foreign languages have not been considered to be essential subjects and are unrelated to others. In addition, teachers think that students can harvest sufficiently knowledge from only discovering Vietnamese materials. Another reason is that English is not necessary for their jobs [5]. Thus, if the weak foreign language capacity does not affect teachers' benefits and students' final results, teachers will not try to use foreign languages in the classroom. This situaton has happened not only 
in our country, but also in many countries in the world [4].

In addition, the list of issues about bilingual teaching in high schools has been pointed out: How are bilingual education programs designed?; How are bilingual documents used more effectively?; Which grade should bilingual teaching start from?; How is the teachers' capacity of organizing bilingual lessons improved?; What is the rationale of bilingual education program which not only helps students to be able to get international foreign language certificates but also develops their foreign language competence?; What is the role of high schools? [1, 5].

In conclusion, building processes of organizing English-Vietnamese bilingual biology lessons in high school has been one of the urgent issues.

\section{Theore TICAL FRAMEWORK and research methods}

\subsection{Theoretical framework}

2.1.1. Bilingual learning and teaching

(a). Definitions

Bonces (2012) pointed out that "content and language integrated learning (CLIL) describes educational methods in which subjects are taught through a foreign language with dualfocused aims, namely the learning of content, and the simultaneous learning of a foreign language" [6]. According to Dalton-Puffer (2011), CLIL is interpreted as a foreign language enrichment measure packaged into content teaching [7]. Another study showed that CLIL is an educational method in which a foreign language learning is integrated into science's content learning and teaching activities [8]. These definitions clearly shows how CLIL not only implies the teaching of content through English but remarks the importance language has when teaching content.

(b). Organizing English-Vietnamese
Organizing English-Vietnamese bilingual lesson is to design teaching activities in English in which with a specific period of time, the teacher controls cognitive activities of a fixed group of same age students, pays attention to characteristics of each student, uses appropriate English materials, teaching equipments and methods. As a result, students not only improve English skills, but also gain basic knowledge and skills, and develop cognitive ability [1].

2.1.2. English-Vietnamese bilingual biology lesson

2.1.2.1. The stages of organizing an English-Vietnamese bilingual biology lesson in classroom

According to Tran Trung Hieu (2017), the process of organizing an English-Vietnamese bilingual biology lesson consists of two main stages: preparation and deployment of bilingual lesson in classroom [1].

Stage 1: Preparing the lesson at home

- Activities of teacher are to build up orientation materials, design the lesson, and orient learning activities of students.

- Activities of students are to receive orientation materials and tasks, ask questions (if any), assign tasks to members of group, decide the solutions, collect information, solve tasks, and evaluate themselves.

Stage 2: Deploying bilingual the lesson in the classroom

The study built up the process of deploying a bilingual lesson in the classroom including six steps (Figure. 1).

2.1.1.3. Levels of English-Vietnamese bilingual biology lessons

The study proposed three levels of EnglishVietnamese bilingual biology lessons in high school (Table 1).

\subsection{Research methods}

\subsubsection{Method of investigation}

The purposes are to gather accurate information on students' English ability and high school teachers' organizing EnglishVietnamese bilingual biology lesson. bilingual lessons 
The ways to inquire are conversing, interviewing and using questionnaires. The study investigated 457 students and 27 high school teachers in An Giang province.

The process of inquiring is carried out in four steps: (1) Identify the purposes of the

Activities of

teacher

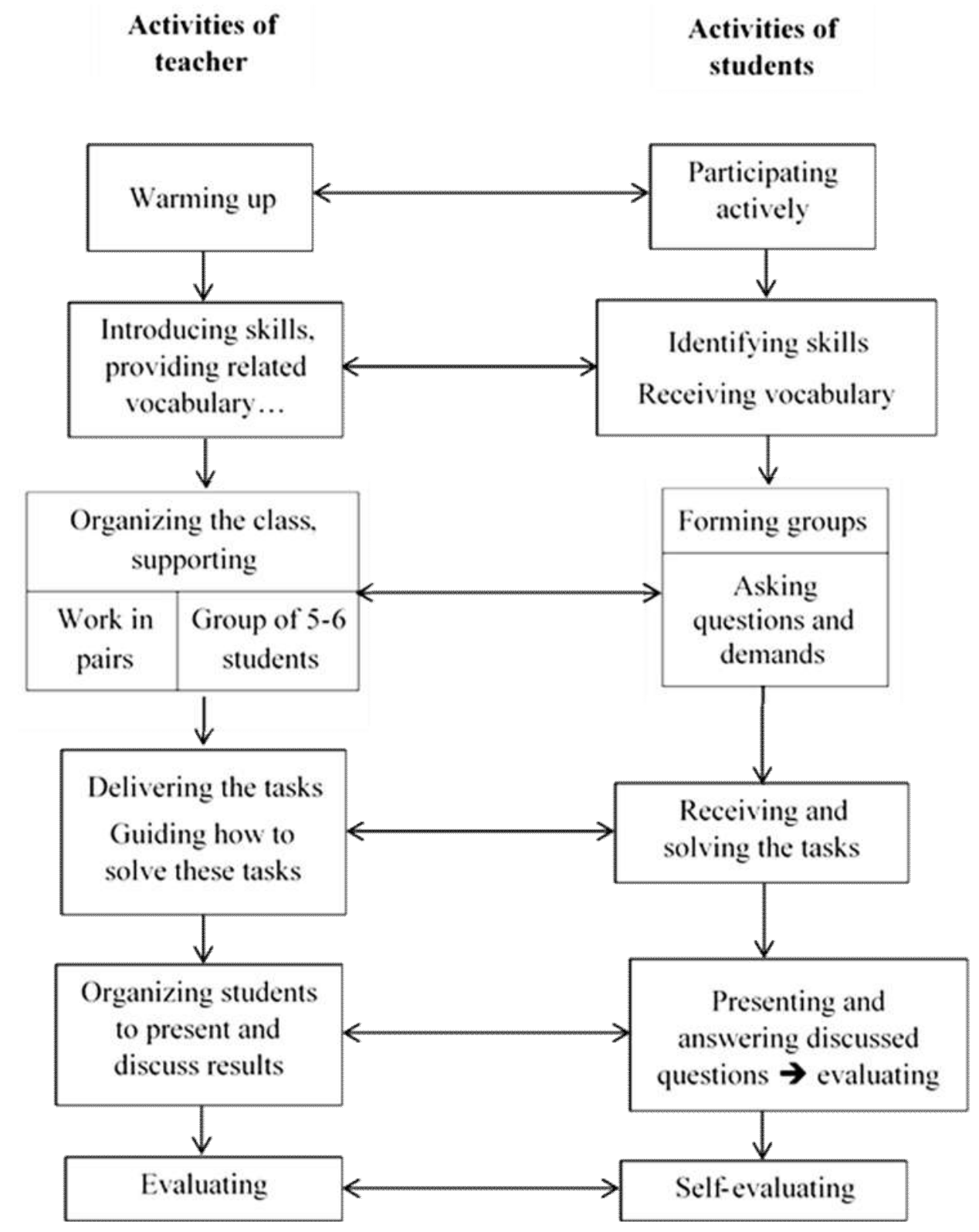

Figure 1. The process of deploying a bilingual lesson in the classroom. survey; (2) Determine respondents $\left(10^{\text {th }}\right.$ grade students and biology teachers in high school); (3) Design the questionnaires; (4) Inquire and process gathered results. 
Table 1. Levels of English-Vietnamese bilingual biology lessons

\begin{tabular}{|c|c|c|}
\hline Levels & Activities of teacher & Activities of students \\
\hline 1 & $\begin{array}{l}\text { - Deliver English exercises (with } \\
\text { specific guides) which students will } \\
\text { solve at home. } \\
\text { - Organize learning activities in the } \\
\text { classroom: } \\
+ \text { Vietnamese language is used } \\
\text { mainly. } \\
+ \text { English language is used to fix } \\
\text { exercises of individuals or groups. }\end{array}$ & $\begin{array}{l}\text { - Activities at home: search information, } \\
\text { cooperate with others to finish exercises in } \\
\text { English. } \\
\text { - Activities in the classroom: (1) } \\
\text { Vietnamese language is used mainly; (2) } \\
\text { The groups discuss to solve English } \\
\text { exercises. }\end{array}$ \\
\hline 2 & $\begin{array}{l}\text { - Deliver English exercises (with } \\
\text { specific guides) which students will } \\
\text { solve at home. } \\
\text { - Organize learning activities in the } \\
\text { classroom: } \\
+ \text { English language is used mainly } \\
\text { (depending on suitable contents of } \\
\text { lesson). } \\
+ \text { English language is used to fix } \\
\text { exercises. }\end{array}$ & $\begin{array}{l}\text { - Activities at home: (1) Search } \\
\text { information, cooperate with others to finish } \\
\text { exercises in English; (2) English language } \\
\text { is used mainly in discussing activities. } \\
\text { - Activities in the classroom: (1) English } \\
\text { language is used mainly in discussing, } \\
\text { solving exercises and presenting results; (2) } \\
\text { Vietnamese language is used to present } \\
\text { discussed results (some English words are } \\
\text { also used). }\end{array}$ \\
\hline 3 & $\begin{array}{l}\text { - Deliver English exercises (with } \\
\text { specific guides) which students will } \\
\text { solve at home. } \\
\text { - English language is used in all } \\
\text { learning and teaching activities in the } \\
\text { classroom. }\end{array}$ & $\begin{array}{l}\text { - Activities at home: (1) Search } \\
\text { information, cooperate with others to finish } \\
\text { exercises in English; (2) English language } \\
\text { is used in all discussing acitivities. } \\
\text { - Activities in the classroom: (1) Solving } \\
\text { the tasks such as discussing, arguing and } \\
\text { presenting in English language; (2) English } \\
\text { language is used to present discussed } \\
\text { results in short outlines or figures. }\end{array}$ \\
\hline
\end{tabular}

2.2.2. Method of pedagogical experimentation and mathematical statistics

The purpose is to confirm the feasibility of proposed solutions.

Experimental objects: $10^{\text {th }}$ Grade students.

The process of experiment is carried out in six steps: (1) identify the experimental and control groups (these groups have to be equivalent to English ability), and evaluate students' qualification and English ability in these groups; (2) select appropriate lessons and design lesson plans; (3) discuss high school teachers who will teach experimental lessons; (4) deploy the lesson plans designed for the experimental group; (5) test, mark, and evaluate students' answers; (6) and process gathered information and data based on mathematical statistics, and evaluate results.

\section{Findings}

\subsection{Designing an English-Vietnamese bilingual biology lesson}

In the process of organizing EnglishVietnamese bilingual biology lesson, the preparation phase plays an important role as it affects the success of deployment phase. Therefore, to create the good and effective script, the teacher has to be not only knowledgeable about major and pedagogical skills, but also proficient in English.

According to Tran Ba Hoanh (1993), Dinh Quang Bao \& Nguyen Duc Thanh (1998), Phan Duc Duy (1999), Nguyen Van Hien (2009), the biology lesson is planned in some basic steps, such as identify learning objectives, determine teaching aids, define educational methods, and 
organize learning activities [9-12]. Thus, in order to have an effective English-Vietnamese bilingual biology lesson, the study has proposed a process represented in Figure 2.

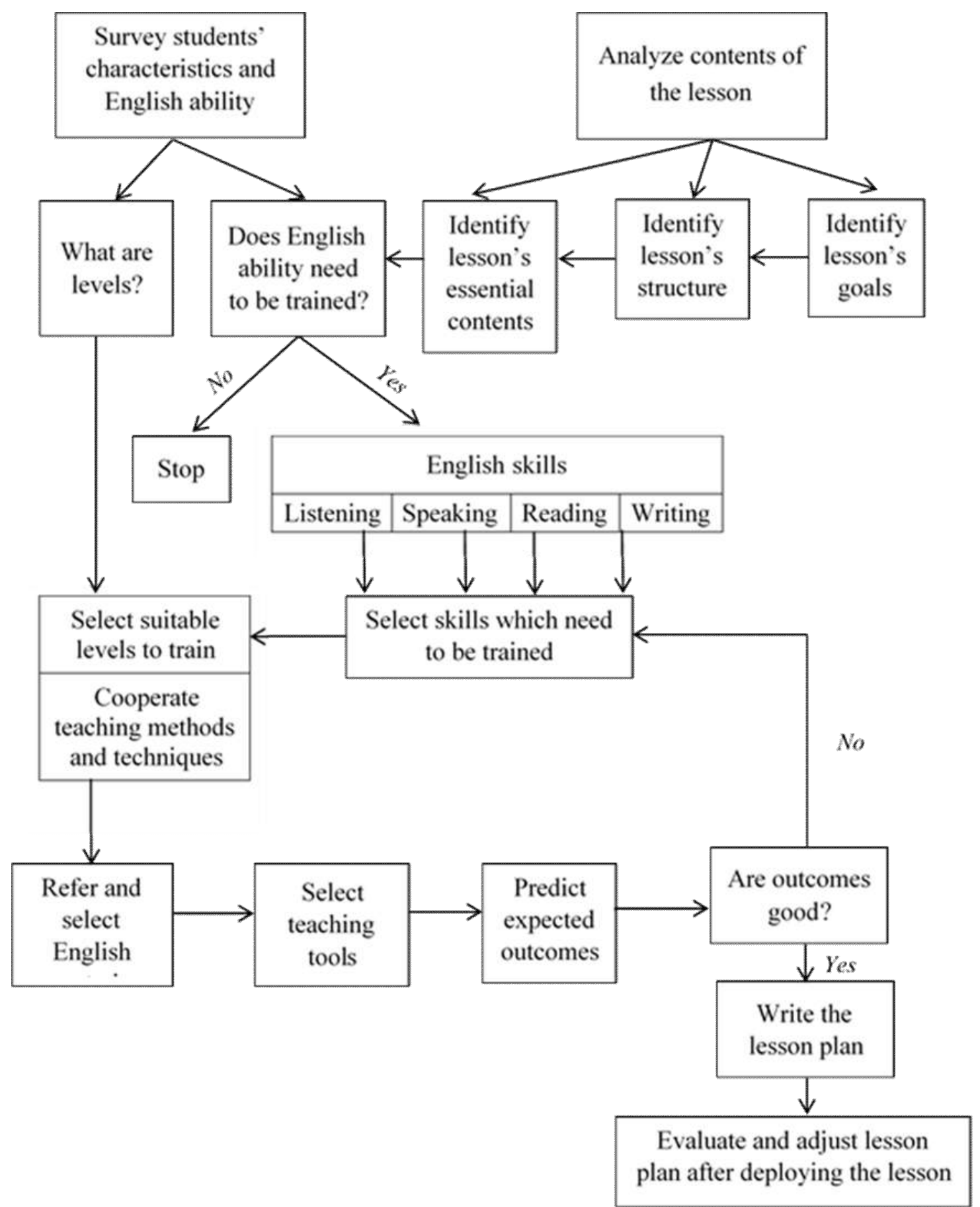

Figure 2. The process of developing an English-Vietnamese bilingual biology lesson. 
Step 1: Analyze contents of the lesson

- Identifying the goals of the lesson is important and indispensable because they are requirements and aims which students have to achieve after finishing the lesson. In other words, the goals are the measure of outcomes of the teaching process. Based on these goals, the teacher can define necessary tasks such as how to control students' discovery activities, how to guide students to apply learnt knowledge and skills in solving exercises, and what lessons students will gain. In addition, defining the goals has to base on education program's standards of knowledge, skills and competencies.

- Analyzing the structure of the lesson aims to identify relations between learnt knowledge and skills and the knowledge and skills that students will be formed so that the teacher can design learning activities effectively.

- The facts showed that mastering the lesson's structure allows the teacher not only to outline lesson's units but also to be able to adjust the logic of these units. Moreover, this master benefits the teacher from building up the systems of questions and exercises which help students to apply harvested knowledge and skills in their learning activities appropriately.

Step 2: Survey students' characteristics and English ability

In order to identify English skills and appropriate levels which need to be trained, the teacher has to evaluate students on qualification, English ability, and psychological features. The results of this survey allow the teacher to collect and combine teaching techniques and methods effectively in training process.

Step 3: Select and combine teaching techniques and methods

When selecting and combining teaching techniques and methods, the teacher has to pay attention to: promoting students' activeness, initiative and creativity; training self-learning and cooperative learning skills; problem solving competence; and creating excitement in the classroom.

Step 4: Refer to English biology materials
Finding and collecting English biology materials is one of the most important steps in the process of designing bilingual lesson. This collecting requires teacher's considerable time and effort. Moreover, integrating these collected materials into bilingual lesson has to suit contents of lesson and students' English ability. Then, the teacher will choose appropriate teaching tools.

Step 5: Predict expected outcomes

The teacher needs to predict the knowledge, English skills and competencies which students can gain through the lesson. Unless these outcomes are as expectations, previously identified English skills, the materials and teaching methods, techniques and tools have to be re-evaluated entirely to have more appropriate selections and co-operations among them.

The teacher only begins writing the lesson plan when these outcomes have been evaluated fully and entirely.

Step 6: Write the lesson plan

A lesson plan must ensure some requirements: (1) suit the standards of knowledge, skills and competencies provided by the Vietnamese Ministry of Education and Training (MoET); (2) ensure to improve students' English skills; (3) and organize various teaching activities and promote students' self-learning and creativity.

Step 7: Evaluate and adjust lesson plan after deploying the lesson

After finishing the lesson in the classroom, the teacher will review and evaluate the success of the lesson to harvest experiences, find out shortcomings, and then adjust designed lesson (if any).

\subsection{Results of investigation}

3.2.1. Current state of organizing EnglishVietnamese bilingual biology lesson in high school

By conversing, discussing and inquiring 27 high school biology teachers in An Giang province, the study has pointed out that: 
- Organizing English-Vietnamese bilingual biology lessons still limits. Only a few seminars of bilingual lesson are annually held at some schools.

- Bilingual teaching has been developed individually. An effective measure to design and organize an English-Vietnamese bilingual biology lesson has been still provided.

- Majority of teachers cannot organize the bilingual lesson due to their limited English capacity.

- There have not had any supported subsidies for the teachers who can teach bilingually from the government.
Thus, organizing bilingual lesson in high school has been facing many difficulties and limitations.

3.2.2. English ability of $10^{\text {th }}$ Grade students

The results (Table 2) have showed that the number of students who have weak listening and reading skills is quite high. In the meanwhile, the number of students who have fair English abilty (especially speaking skill) is highest. One of the reasons of this state is that students rarely use English in subjects learning except English.

3.2.3 Current state of $10^{\text {th }}$ Grade students' excitement with bilingual teaching activities of biology teachers in high school

Table 2. $10^{\text {th }}$ Grade students' ability to use English

\begin{tabular}{lllllllll}
\hline \multirow{2}{*}{$\begin{array}{l}\text { English } \\
\text { skills }\end{array}$} & \multicolumn{1}{l}{ Levels } & \multicolumn{1}{l}{ Excellent/very good } & Good & \multicolumn{3}{c}{ Fair } & \multicolumn{3}{l}{ Poor } \\
\cline { 2 - 9 } & Number & Rate (\%) & Number & Rate (\%) & Number & Rate (\%) & Number & Rate (\%) \\
\hline Listening & 19 & 4.2 & 62 & 13.6 & 225 & 49.2 & 151 & 33.0 \\
Speaking & 11 & 2.4 & 65 & 14.2 & 327 & 71.6 & 54 & 11.8 \\
Reading & 25 & 5.5 & 96 & 21.0 & 259 & 56.7 & 77 & 16.9 \\
Writing & 27 & 5.9 & 112 & 24.5 & 284 & 62.1 & 34 & 7.4 \\
\hline
\end{tabular}

Table 3. Reasons of students' unexciting feelings with bilingual biology lessons

\begin{tabular}{llll}
\hline No & Causes & Number of students & Rate (\%) \\
\hline 1 & Limited English ability & 422 & 92.3 \\
2 & $\begin{array}{l}\text { Rare using English in subjects except English } \\
\text { subject }\end{array}$ & 457 & 100 \\
3 & $\begin{array}{l}\text { Do not understand teachers' questions } \\
\text { Are not aware of important role of English in } \\
4\end{array}$ & 213 & 46.6 \\
\hline
\end{tabular}

The results (Table 3) have showed that one of reasons of this state is the majority of students' limited English ability. So the teachers should apply suitable levels of bilingual lessons so that students can follow and improve gradually. In addition, another cause is that biology is one of abstract subjects, so the teachers have held bilingual teaching activites rarely.

The study has also discovered that "effective bilingual lessons" which are designed with live pictures and videos, organized through the games, taught particularly and carefully and do not cause grade pressures are students' expectations.

\subsection{Experimental results}

\subsubsection{The results of entrance test}

Two curves (Figure. 3) which show students' cumulative frequencies of grades in experimental and control groups nearly coincide. In addition, although 
$\overline{\mathrm{x}}_{\mathrm{IC}}$ (EC: experimental group) and $\overline{\mathrm{x}}_{\mathrm{CC}}$ (CC: control group) are different, the mathematical statistics' results on entrance tests showed that $t$ $=1.39<\mathrm{t}_{\mathrm{cs}}=2.081(\alpha=0.02)$. Therefore, the difference between $\overline{\mathrm{x}}_{\mathrm{IC}}$ and $\overline{\mathrm{x}}_{\mathrm{CC}}$ does not have statistical significance. Thus, the qualification of these two groups of students is identical.

Table 4. Parameters of test results - entrance assessment

\begin{tabular}{lllll}
\hline Groups & Sample size (students) & $\overline{\boldsymbol{x}}$ & $\mathrm{S}^{2}$ & $\mathrm{~S}$ \\
\hline Experiment group & 127 & 6.26 & 2.64 & 1.63 \\
Control group & 121 & 6.54 & 2.38 & 1.54 \\
\hline
\end{tabular}

The average grade of students in the experimental and control group is slightly different (Table 4).

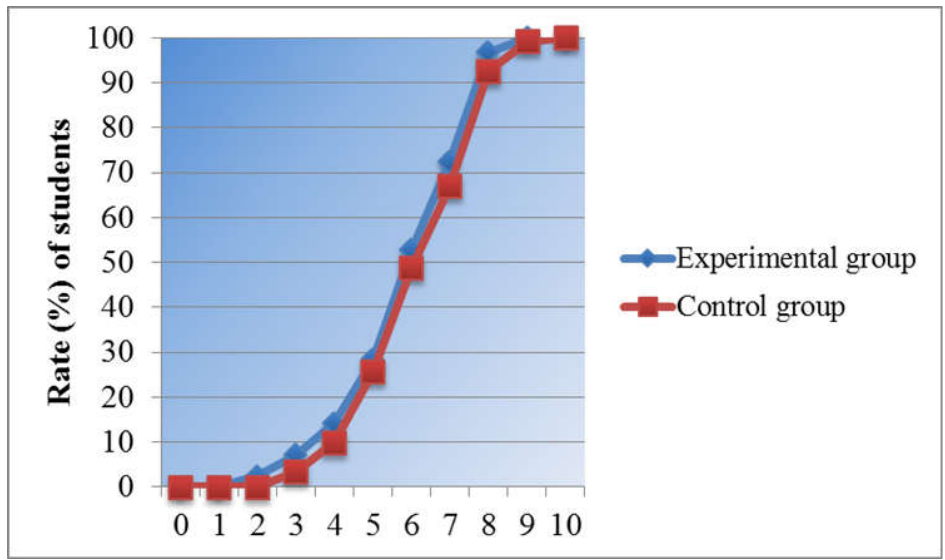

Figure 3. Cumulative frequency of entrance tests in the experimental and control group (Knowledge tests).

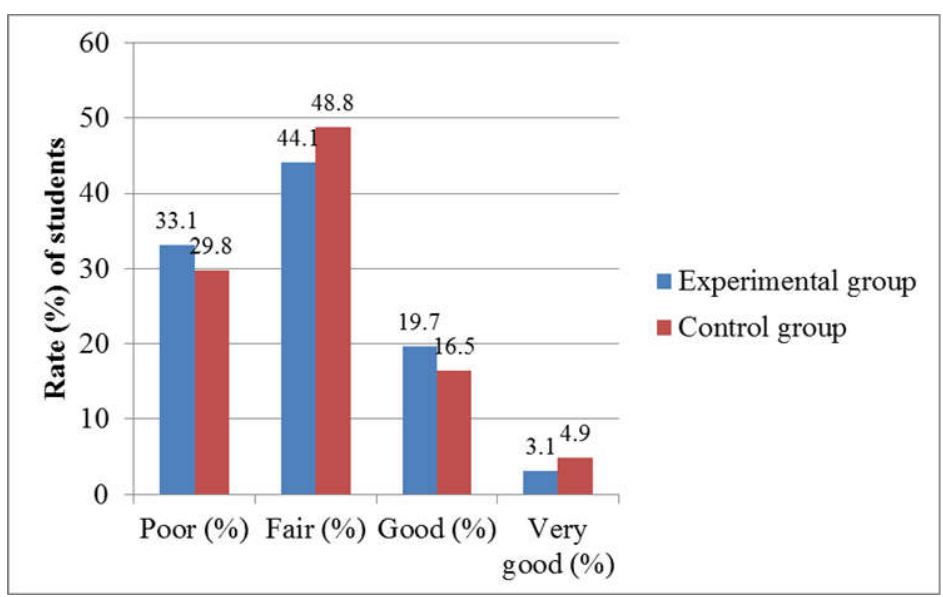

Figure 4. Comparision of students' English ability in the control and experimental groups (Entrance tests).

The results of entrance tests (Figure. 4) have demonstrated that English ability of students in the two groups may be considered as similarity.
3.3.2. The results of outcomes test

The average grade of students in the experimental group increased from 6.06 to 6.76 and this grade in the control group decreased to 0.26 (Table 5). 
Table 5. Parameters of test results - outcomes assessment

\begin{tabular}{lllll}
\hline Groups & Sample size (students) & $\overline{\boldsymbol{x}}$ & $\mathrm{S}^{2}$ & $\mathrm{~S}$ \\
\hline Experiment group & 127 & 6.76 & 2.83 & 1.68 \\
Control group & 121 & 6.28 & 2.92 & 1.71 \\
\hline
\end{tabular}

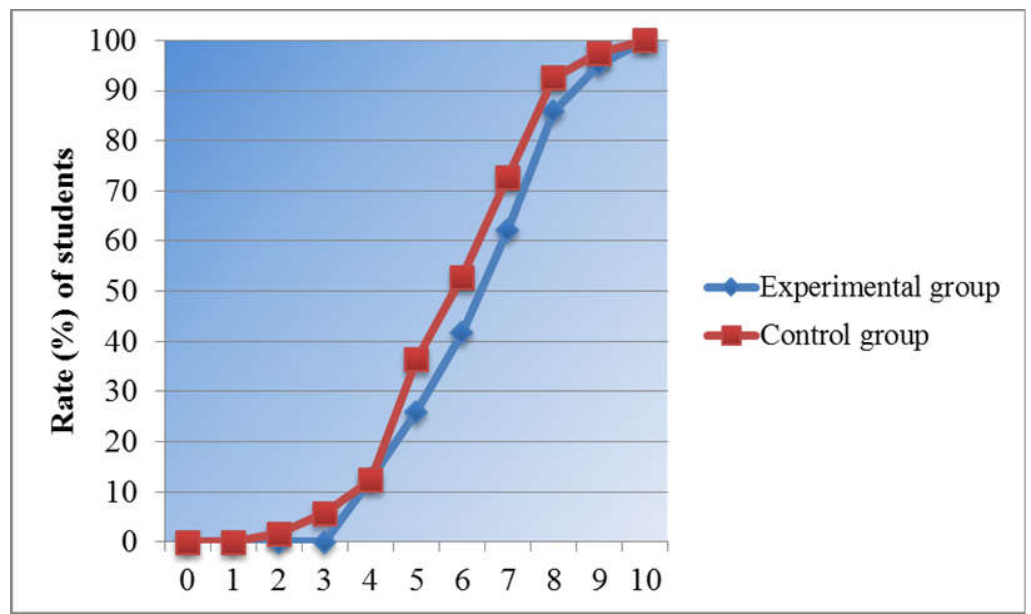

Figure 5. Cumulative frequency of outcomes tests in the experimental and control groups (Knowledge tests).

- The curve (Figure. 5) which shows students' cumulative frequencies of grades in experimental group is below this curve in control group. Thus, the rate of high scored students in experimental group is higher than this rate in control group. In addition, experimental group's average grade increased significantly although it has lower entrance result than control group.

- Results of statistical testing on outcomes tests showed that $\mathrm{t}=2.22>\mathrm{t}_{c \mathrm{c}}=2.081(\alpha=$ 0.02). Therefore, the difference between $\bar{x}_{\mathrm{EC}}$ and $\overline{\mathrm{x}}_{\mathrm{Cc}}$ has statistical significance. Thus, students' learning outcomes in the experimental group were significantly higher than that of the control group.

- The experimental group had decreased rate of students with poor and fair grades, significantly increased rate of good scored students (from 19.7\% to $29.1 \%$ ). Especially, the rise of excellent rate is nearly double.

- Control group's English ability is almost unimproved.
These results have demonstrated the reliability and feasibility of proposed processes of organizing English-Vietnamese bilingual biology lesson in high school.

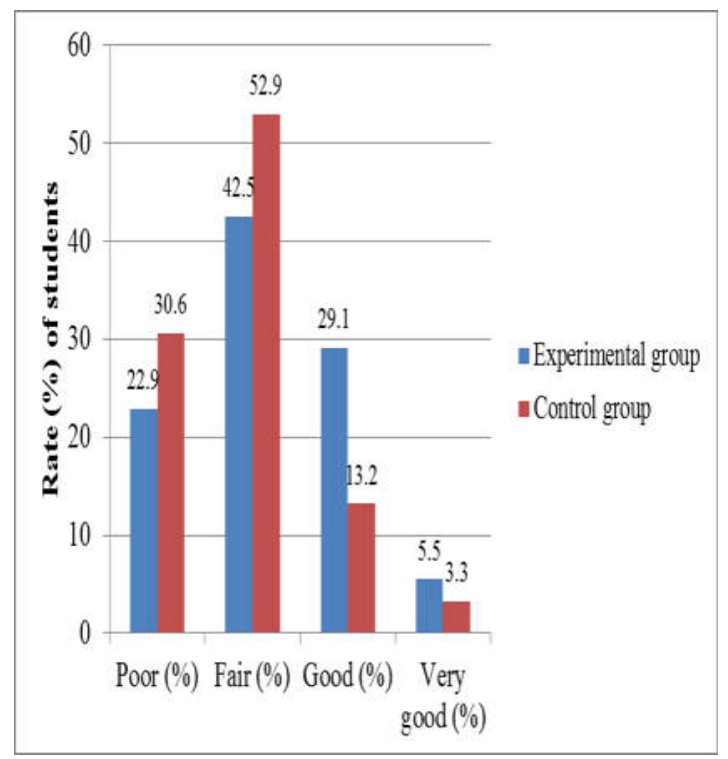

Figure 6. Comparision of students’ English ability in the control and experimental group (Outcomes tests). 


\section{Conclusion}

The investigated results show that organizing English-Vietnamese bilingual lessons in high schools is ineffective and limited. This is one of the most important reasons effecting poor English ability in high school students. In addition, the study has also demonstrated that the proposed processes of organizing English-Vietnamese bilingual biology lesson have not only improved students' English ability but also raised the quality of biology teaching in high school. Moreover, the study also discovered that in order to organizing a English-Vietnamese bilingual biology lesson more successfully, some factors such as equipments, teaching techniques, pratical case studies and student's active motivation.

In order to partially improve high school students' weakness on foreign language, especially English, the MoET, local Service of Education and Training, each school board and class teachers have to "join hands" in developing the strategy of bilingual teaching. The study also calls for young teachers to enthusiastically organize bilingual teaching activities. These activities contribute to developing English ability of young generation for international integration purpose.

\section{References}

[1] Tran Trung Hieu, Organizing English-Vietnamese bilingual lessons in biology teaching in high school, Teacher of Vietnam Scientific Magazine, 123 (2017) 37.
[2] Nha, T. T. V., \& Burn, A., English as a medium of instruction: Challenges for Vietnamese tertiary lecturers, The journal of Asia TEFL, 11 (2014) 1.

[3] Thuong Nguyen, Vietnam national foreign language 2020 project after 9 years: A difficult stage, The Asian Conference on Education \& International Development 2017, National Chengchi University, Taiwan, 2017.

[4] Hadisantosa, N., Huong, T. T. T., Johnstone, R., Keyuravong, S., \& Lee, W., Learning through English: Policies, challenges and prospects (Insight from East Asia), Malaysia: British Council, (2010).

[5] Dong Hai Nguyen, Bilingual education in Vietnam: Successes and challenges, Cambrigde Educational Leadership Seminar, Ho Chi Minh city, 2013. Retrieved from ttp://www.cambridgeassessment.org.uk/images/13 7032-dr-dong-hai-nguyen-presentation-slides-.pdf

[6] Bonces, J. R, Content and language integrated learning (CLIL): Considerations in the Colombian context, Gist Education and Learning Research Journal, 6 (2012) 177.

[7] Dalton-Puffer, C, Content-and-language integrated learning: From practice to principles? Annual Review of Applied Linguistics, Cambridge University Press, 31 (2011) 182.

[8] Dao Thi Hoang Hoa, Teaching Chemistry through the medium of English using content and language integrated learning approach, Journal of Science, Ho Chi Minh city University of Education, 54 (2014) 29.

[9] Dinh Quang Bao \& Nguyen Duc Thanh, Theories of biology teaching, Vietnam Education Publishing House, 1998.

[10] Tran Ba Hoanh, Techniques of biology teaching, Vietnam Education Publishing House, 1993.

[11] Phan Duc Duy, Trainning biology teaching skills for students based on studying pedagogy cases, Doctor thesis, Hanoi National University of Education, Hanoi, Vietnam, 1999.

[12] Nguyen Van Hien, Developing the skills of applying information technology in organizing biology lessons in students, Doctor thesis, Hanoi National University of Education, Hanoi, Vietnam, 2009. 


\title{
Tổ chức bài học Sinh học song ngữ Anh-Việt để phát triển kỹ năng tiếng Anh cho học sinh trung học phổ thông
}

\author{
Trần Trung Hiếu \\ Khoa Su phạm, Truờng Đại hoc An Giang, Số 18 Ung Văn Khiêm, \\ Phuờng Đông Xuyên, Thành phố Long Xuyên, Tỉnh An Giang, Việt Nam
}

Tóm tắt: Tiếng Anh là một trong những công cụ quan trọng và cần thiết cho sự thành công trong nhiều phương diện của mỗi người. Do đó, việc xây dựng các biện pháp để phát triển kỹ năng tiếng Anh cho người học là một đòi hỏi cấp bách. Tổ chức bài học song ngữ Anh-Việt là một phương pháp dạy học nhằm làm giàu một ngoại ngữ và nó được "đóng gói" trong hoạt động dạy học nội dung các môn học. Vì vậy, đây được xem là một trong những biện pháp hiệu quả để phát triển kỹ năng tiếng Anh cho học sinh. Bằng việc khảo sát 457 học sinh và 27 giáo viên ở các trường trung học phổ thông trong tỉnh An Giang, nghiên cứu đã xác định hai vấn đề về thực trạng của việc sử dụng tiếng Anh trong dạy học Sinh học ở trường phổ thông hiện nay: (1) Giáo viên ít khi sử dụng tiếng Anh trong các hoạt động dạy học, (2) Năng lực tiếng Anh của học sinh khá yếu. Nghiên cứu cũng đã xây dựng các quy trình tổ chức một bài học song ngữ Anh-Việt. Bài báo còn chứng minh rằng: với việc sử dụng những quy trình này, chất lượng dạy học và kỹ năng tiếng Anh của học sinh đã được cải thiện.

Tù khóa: Bài học sinh học song ngữ, dạy học song ngũ̃, năng lực tiếng Anh, dạy học sinh học. 